\title{
Fate riding on their horns-and genes?
}

\author{
Nigel Lea DeR - Williams
}

The members of the rhinoceros family-perennially in demand for their valuable horns-have posed challenges for conservation since the late 19th century. Their genetic diversity continues to be irretrievably lost. Meanwhile, some species are recovering, although their long-term future is not assured. So rhinos are a family of mixed fortunes. This issue of Oryx puts the focus on two living species of Asian rhinos. Goossens et al. (2013) address the plight of the Sumatran rhino Dicerorhinus sumatrensis, and Thapa et al. (2013), Subedi et al. (2013) and Murphy et al. (2013) address the recovery of the greater onehorned, or Indian, rhino Rhinoceros unicornis in Nepal.

Currently, there are five living species of rhino-but only just! Two species in Asia, the Javan Rhinoceros sondaicus and the Sumatran, and one species in Africa, the black Diceros bicornis, are categorized as Critically Endangered on the IUCN Red List. The Indian rhino is categorized as Vulnerable and the white rhino Ceratotherium simum of Africa as Near Threatened.

The Javan rhino, once widespread across lowland forests of South-east Asia, competed for land with increasingly dense human populations. The Indian subspecies $R$. sondaicus inermis became extinct before 1925 . However, 30-50 individuals of the type subspecies have persisted in a single population under the protective shadow of Krakatoa on the western tip of Java since the 1930s. An even smaller population of $c .15$ of the Vietnamese subspecies $R$. sondaicus annamiticus, thought extinct in the mid 1970s in a former war zone, was rediscovered in 1989. However, the last individual was found dead in 2010, with its nose hacked off (Brook et al., 2012) - like so many other rhinos killed for their horns in both Asia and Africa.

Black rhinos were formerly widespread across sub-Saharan Africa but faced competition from bush clearance following European settlement. An onslaught of killing for their horns further decimated the continental population from perhaps 65 ,000 in the 1970 s to $<2,500$ in 2004 . The species became locally extinct over much of Africa, and the western subspecies D. bicornis longipes continued its slide towards eventual extinction in Cameroon in 2011.

The northern white rhino C. simum cottoni (which may be a separate species C. cottoni; Groves et al. 2010) became extinct in the wild in 2008. Persisting as a single population of c. 30 animals in an area of conflict between the Democratic Republic of Congo and Sudan, their long-term prospects had looked unpromising since the 1980 s. However, prevarication delayed decisions over how to align the few remaining wild and captive

Nigel Leader-Williams Department of Geography, University of Cambridge, Cambridge, UK. E-mail nl293@cam.ac.uk rhinos. Finally, four of six rhinos remaining in captivity in the Czech Republic were transported to a Kenyan conservancy in 2009. Whether this remnant group can form an effective metapopulation through cross-breeding with the southern white rhino C. simum simum remains to be seen.

In the light of two subspecies of rhinos becoming extinct and one subspecies, or possibly species, becoming extinct in the wild, during the last decade, Goossens et al. (2013) make radical proposals to ensure a future for the Sumatran rhino. This species was once widespread across steep, forested terrain in South-east Asia. Its slide towards extinction has passed largely undocumented but threats include forest loss and killing for their horns.

Originally comprising three subspecies, the northern Sumatran rhino D. sumatrensis lasiotis of India and Myanmar has been extinct for several decades, while the Sumatran D. sumatrensis sumatrensis and the Bornean D. sumatrensis harrissoni subspecies have declined to a combined total of probably $<100$ rhinos. In the 1980 s some saw captive breeding in western zoos as the best hope for the survival of 'doomed' Sumatran rhinos. But several captive rhinos died in ex situ facilities and zoo births proved difficult to achieve, so the emphasis switched to breeding in sanctuaries in range. However, some sanctuary rhinos are too old to breed and some males are interrelated. With so few Sumatran rhinos remaining in fragmented wild populations, Goossens et al. (2013) propose collapsing the remaining populations of both subspecies (sumatrensis and harrissoni) into one breeding and management unit that prioritizes demography over genetic distinctiveness. They argue that further prevarication will only serve to ensure that the Sumatran rhino soon becomes extinct. IUCN convened the Sumatran Rhino Crisis Summit in March 2013 to broker agreement between the two range states of Indonesia and Malaysia.

The Indian rhino and the white rhino have made strong recoveries after being reduced to very low numbers in the $1890 \mathrm{~s}$ and early 190os. The Indian rhino, so elegantly woodcut by Durer in 1515, was once widespread across the floodplains of the Ganges, Indus and Brahmaputra rivers. Rhinos were hunted heavily by native and colonial rulers during the 1800 s and 1900s. In India, rhinos were reduced to remnant populations by the early 1900s. However, Kaziranga and a network of other protected areas were established from 1908 onwards and rhino numbers in India increased, to reach c. 2,300 by 2008.

In contrast, Indian rhinos remained numerous in the Chitwan valley of Nepal until malaria was eradicated in the 1950s. Following land clearance for human settlement rhinos were hunted for their horns (Thapa et al., 2013). Even though afforded some protection, rhinos suffered a catastrophic decline 
during the 1960s. But protection was enhanced by declaring Chitwan a national park in 1973, placing it under army control in 1975, retrenching guards to protect the core area in 1993, and establishing community programmes in buffer areas. In addition, 87 rhinos were translocated from Chitwan to seed two new populations but rhinos continue to be killed in both source and translocated populations The conservation of rhinos in Nepal is now underpinned by a standardized monitoring system of block counts carried out on elephantback (Subedi et al. 2013), showing that Nepal held 534 Indian rhinos in 2012. However, the invasive plant mikania is posing new threats to the rhino's habitat (Murphy et al., 2013).

The recovery of the southern white rhino is a conservation success story. Also originally shot for sport, as well as for its fat and as vermin in early 2oth century land clearances, this subspecies was reduced to remnant populations in the late 1890s. Nevertheless, they were recovered, initially through establishing the now iconic protected areas of Hluhluwe and Umfolozi in Zululand in 1895. By the early 1960s, however, protected populations had reached carrying capacity and immobilizing drugs had been developed. Rhinos were therefore darted and moved, initially to other state protected areas and latterly to private land, to create more space for the growing rhino population. As financial incentives, source protected areas could sell live rhinos, and private landowners could buy rhinos and offer opportunities for sustainable sport hunting. By 2010 white rhinos had recovered in the wild to a continental total of 20,165, of which 93\% occurred in South Africa.

Among black rhinos the three subspecies in East and southern Africa were mainly consigned to small heavily protected sanctuaries, from which rhinos were translocated to seed new populations in areas of former range and to keep rhinos below ecological carrying capacity and encourage breeding. Cautious optimism surrounded the early stages of this recovery. By 2010 numbers had increased to a continental total of c. 4,880, of which most are held in South Africa, Namibia, Kenya and Zimbabwe. However, an intense wave of illegal killing of African rhinos for their horns has now reared its head, throwing another potential crisis into the paths followed by the rhinoceros family.

Some of the historic threats to rhinos have lessened. Nevertheless, options to preserve genetic diversity continue to foreclose, and the threat of the illegal horn trade needs to be addressed urgently, but even-handedly, if all living taxa of rhinos are to have a future. The prospects for Javan, Sumatran, and northern white rhinos remain hardest to second guess. Conservation opportunities have been lost through previous indecision. For Javan rhinos only one option now remains, to encourage rhino numbers to increase beyond the static population long assumed to have persisted at carrying capacity in Ujung Kulon. This option, first mooted in the 1990s, is to establish a second wild population, possibly in another geopolitical unit, which does not reduce the viability of the source population. For Sumatran rhinos the option of collapsing subspecies into a single breeding and management unit remains-but only for a while. For northern white rhinos much hope rests on the breeding performance of the four once captive rhinos in Ol Pejeta Conservancy in Kenya.

The prospects for Indian, black and southern white rhinos have improved greatly as their numbers have recovered but their future in the wild is by no means assured. Rhinos require freedom to breed and protection from illegal hunting. Various conservation actions have been applied to all three taxa, with the aim of delivering these basic needs. These actions include protection in small areas, improved law enforcement, translocations, the seeding of new populations in wider landscapes, and community-based projects. Other opportunities such as live sales and trophy hunting have also been applied in southern Africa.

Despite these successful recoveries, the illegal trade in rhino horn continues to be a threat, as it was for the last Javan rhino killed in Vietnam, and as it continues to be for the Indian rhino in India and Nepal and for the c. 660 mostly white rhinos killed in South Africa in 2012 alone. Collectively, conservationists have remained path dependent in their approach to the rhino horn trade since 1977 , supporting policies that continue to ban international trade and to seek reductions in demand among end users. However, Biggs et al. (2013) have suggested that it is now time to consider the option of a legal trade based on stockpiled horn from white rhinos in South Africa. Given that recent upsurges in illegal killing threaten even the most spectacular rhino recovery, it may now be timely to examine whether or not a legalized, sustainable and non-lethal form of horn trade could serve the futures of all rhino species better than current policies.

\section{References}

Biggs, D., Courchamp, F., Martin, R. \& Possingham, H.P. (2013) Legal trade of Africa's rhino horns. Science, 339, 1038-1039.

Brook, S.M., van Coeverden de Groot, P., Scott, C., Boag, P., LoNG, B., LEY, R.E. et al. (2012) Integrated and novel survey methods for rhinoceros populations confirm the extinction of Rhinoceros sondaicus annamiticus from Vietnam. Biological Conservation, 155, 59-67.

Goossens, B., Salgado-Lynn, M., Rovie-Ryan, J.J., Ahmad, A.H., Payne, J., Zainuddin, Z.Z., et al. (2013) Genetics and the last stand of the Sumatran rhinoceros Dicerorhinus sumatrensis. Oryx, 47, 340-344.

Groves, C.P., Fernando, P. \& Robovský, J. (2010) The sixth rhino: a taxonomic re-assessment of the Critically Endangered northern white rhinoceros. PLOS ONE, 5, e9703.

Murphy, S.T., Subedi, N., Jnawali, S.R., Lamichhane, B.R., UpAdHyAY, G.P., Kock, R. \& Amin, R. (2013) Invasive mikania in Chitwan National Park, Nepal: the threat to the greater one-horned rhinoceros Rhinoceros unicornis and factors driving the invasion. Oryx, 47, 361-368.

Subedi, N., Jnawali, S.R., Dhakal, M., Pradhan, N.M.B., Lamichinane, B.R., Malla, S. et al. (2013) Population status, structure and distribution of the greater one-horned rhinoceros Rhinoceros unicornis in Nepal. Oryx, 47, 352-360.

Thapa, K., Nepal, S., Thapa, G., Bhatta, S.R. \& Wikramanayake, E. (2013) Past, present and future conservation of the greater one-horned rhinoceros Rhinoceros unicornis in Nepal. Oryx, 47, 345-351. 